\title{
MENGUNGKAP KESIAPAN PRAKTIK AKUNTANSI PADA PERUSAHAAN UMKM DAN PERUSAHAAN INFORMAL MENUJU PPh PASAL 17
}

\author{
Ustman \\ Universitas Madura \\ ustman@unira.ac.id \\ Rika Syahadatina \\ Universitas Madura \\ rikasyahadatina@unira.ac.id
}

\begin{abstract}
This study aims to determine the readiness of MSME actors and informal companies to make financial reports towards Income Tax Article 17. The government issues a Government Regulation for the imposition of final income tax for taxpayers who have a gross income below 4.8 billion, subject to a rate of $0.5 \%$ each. month. The final income tax rate policy cannot be used continuously, because the income tax rate will be reimposed based on the rate of article 17 of net income. Researchers want to know the accounting practices carried out by MSME actors and informal companies in Pamekasan to face Income Tax Article 17. This research will be conducted using direct field interviews by collecting the required data from related parties. The results of the study are based on respondents' answers that MSME and informal business actors are not ready to switch to Article 17. This can also be seen from the weak understanding of SAK ETAP, UMKM, IFRS and Sharia as evidenced by the small percentage value, which is only $33.3 \%$ who know SAK.
\end{abstract}

Keywords: Income Tax Article 17, accounting practices, MSMEs, informal companies

\begin{abstract}
Abstrak
Penelitian ini bertujuan mengetahui kesiapan pelaku UMKM dan perusahaan informal membuat laporan keuangan menuju Pajak Penghasilan Pasal 17. Pemerintah mengeluarkan Peraturan Pemerintah untuk pengenaan pajak penghasilan yang bersifat final bagi wajib pajak yang memiliki pengahasilan bruto dibawah 4,8 miliar dikenakan dengan tarif $0,5 \%$ tiap bulannya. Kebijakan tarif pajak penghasilan yang bersifat final tersebut, tidak dapat digunakan secara terus-menerus, karena tarif pajak pengahasilan akan kembali dikenakan berdasarkan tarif pasal 17 dari laba bersih. Peneliti ingin mengetahui praktik akuntansi yang dilaksanakan oleh pelaku UMKM dan perusahaan informal di Pamekasan menghadapi PPh Pasal 17. Penelitian ini akan dilakukan dengan metode wawancara langsung kelapangan dengan melakukan pengumpulan data
\end{abstract}




\section{$D A A$}

Vol. 5, No. 1, Oktober 2020

yang dibutuhkan dari pihak terkait. Hasil penelitian berdasarkan jawaban responden bahwa pelaku usaha UMKM dan Informal belum siap untuk beralih ke tarif PPh pasal 17. Hal ini juga dapat dilihat dari lemahnya pemahaman SAK ETAP, UMKM, IFRS maupun Syariah yang dibuktikan dengan nilai presentase yang kecil yaitu hanya sebesar 33,3\% yang mengetahui SAK.

\section{Kata kunci: PPh Pasal 17, praktik akuntansi, UMKM, perusahaan informal}

\section{PENDAHULUAN}

Tahun 2018 merupakan tahun ke empat dari pelaksanaan program pembangunan Kabinet Kerja dalam mencapai sasaran-sasaran pembangunan guna mewujudkan kemakmuran dan keadilan sosial bagi rakyat Indonesia. Pemerintah merespon tahun 2018 ini melalui penetapan tema kebijakan fiskal yakni " Pemantapan Pengelolaan Fiskal untuk Mengakselerasi Pertumbuhan yang Berkeadilan". Salah satu strateginya yaitu dengan mengoptimalkan pendapatan negara dengan tetap menjaga iklim investasi (Kementerian Keuangan RI, 2018).

Pendapatan negara dalam postur APBN 2018, pendapatan negara diproyeksikan sebesar Rp. 1.894,7 triliun. Jumlah ini berasal dari penerimaan perpajakan sebesar Rp. 1.618,1 triliun, Penerimaan Negara Bukan Pajak sebesar Rp. 275,4 triliun dan Hibah sebesar Rp. 1,2 triliun. Data dari penerimaan perpajakan dari tahun 2014 sebesar Rp. 1.146,9 T naik $6,5 \%$ dari tahun 2013, kemudian tahun 2015 sebesar Rp. 1.240,4 T naik 8,2\%, tahun 2016 sebesar $1.285 \mathrm{~T}$ naik 3,6\%, tahun 2017 sebesar Rp. $1.472,7 \%$ naik $14,6 \%$, dan pada tahun 2018 mencapai sebesar Rp $1.618,1 \mathrm{~T}$ naik $10 \%$. Penerimaan perpajakan ini naik diakibatkan adanya perbaikan iklim investasi dunia usaha, termasuk pemberian insentif dan mengoptimalkan potensi ekonomi dan langkah reformasi perpajakan (Kementerian Keuangan RI, 2018).

Sumber pendapatan utama negara adalah dari penerimaan pajak, pajak adalah kontribusi Wajib Pajak kepada negara yang terutang oleh pribadi maupun badan yang bersifat memaksa yang diatur oleh undangundang. Pajak merupakan sumber dana yang memiliki kontribusi penting dalam menjalankan roda pemerintahan untuk melakukan pembangunan, kesejahteraan rakyat dari segi kesehatan, pendidikan maupun yang lainnya.

Sebagai sumber pendapatan utama negara, pemerintah terus melakukan berbagai upaya untuk meningkatkan pendapatan dari sektor perpajakan. Pemungutan pajak pada awalnya menggunakan official assesment system yaitu sistem pemungutan pajak yang memberi kewenangan pemerintah untuk menentukan besarnya pajak yang terutang (Ikatan Akuntan Indonesia, 2013). Kemudian pemungutan pajak berubah 
menjadi self assesment system dimana wajib pajak harus dapat menyiapkan laporan keuangannya dan menghitung, memperhitungkan, menyetor, dan melaporkan pajak terutangnya sendiri. Perubahan sistem pemungutan pajak ini diharapkan wajib pajak dapat menumbuhkan kesadaran diri untuk membayar pajak.

Pemungutan pajak sistem self assesment ini dikenakan oleh semua pelaku usaha yang menjadi wajib pajak, baik itu perusahaan yang sudah go public maupun perusahaan UMKM atau perusahaan informal seperti pedagang kaki lima. Semua yang memiliki penghasilan akan dikenai pajak pengahasilan. Maka dari itu perusahaan wajib membuat laporan keuangan sebagai dasar pengenaan pajak bagi pemerintah, tidak terkecuali dengan perusahaan UMKM atau perusahaan informal seperti pedagang kaki lima.

Perusahaan yang telah go public atau perusahaan yang sudah berbentuk badan hukum tidak akan kesulitan dalam membuat laporan keuangan berdasarkan Standar Akuntansi Keuangan (SAK) dan menghitung, menyetor dan melaporkan pajaknya. Perusahaan besar sudah memiliki semua unsur dalam struktur perusahaan, misalnya staf keuangan dan tax planing. Akan berbeda jika melihat perusahaan UMKM dan perusahaan informal, hampir seluruhnya perusahaan informal ini tidak memiliki pengetahuan dalam membuat informasi keuangan berupa laporan keuangan yang sesuai SAK.

Triyuwono (2011) berpendapat, bahwa kita harus mengkaji kasus akuntansi pinggiran sebagaimana kita mengkaji yang pusat. Dengan cara pandang yang berbeda, akuntansi dapat menjadi bukti bahwa pada dasarnya ilmu pengetahuan dan praktiknya bersifat tidak bebas nilai melainkan syarat akan nilai (Agustuliani dan Majid, 2016). Akuntansi selama ini dipahami hanya untuk perusahaan besar saja. Oleh karena itu akuntansi sering diukur dengan satuan material yang banyak sehingga mereka yang merupakan realitas kecil tidak banyak menjadikan akuntansi sebagai instrumen bisnis (Sakri et al, 2018)

Akuntansi juga dilakukan oleh perusahaan informal, akan tetapi tidak sesuai dengan SAK. Pelaku usaha tersebut mencatat dengan pengetahuan yang mereka miliki. Misalnya operasional yang dilakukan oleh Mantong (seorang supir panther) dimulai dari mendaftar penumpang, berangkat subuh dan perhitungan transaksi keuangan saat rumahnya dimalam hari sudah tertutup kemudian menandakan bahwa transaksi untuk hari ini telah selesai (Juardi, 2016). Dari kejadian ini bahwa supir panther telah memberikan gambaran bahwa pencatatan keuangan telah dilakukan oleh pelaku usaha informal.

Dari kejadian seorang supir panther di atas, maka pemerintah terus melakukan berbagai upaya untuk terus memperoleh pendapatan dari pajak. Pemerintah tidak begitu memusingkan pendapatan pajak penghasilan yang diperoleh dari perusahaan besar atau yang telah go public. Pemerintah juga berharap ada pemasukan pendapatan pajak 
pengahasilan dari perusahaan UMKM dan perusahaan informal. Pemerintah mengetahui kelemahan dari pelaku usaha UMKM dan perusahaan informal itu pada point pelaporan keuangan. Maka dibuatlah aturan tarif pengenaan pajak penghasilan yang bersifat final yang tertuang dalam Peraturan Pemerintah Republik Indonesia No 23 tahun 2018. Perusahaan UMKM dan perusahaan Informal yang menjadi wajib pajak yang memiliki pengahasilan bruto dibawah 4,8 miliar dikenakan pajak pengahasilan dengan tarif $0,5 \%$ tiap bulannya tanpa melihat laba/rugi, biaya yang dikeluarkan selama berjalannya usaha.

Tarif pajak pengahasilan yang bersifat final PP no 23 tahun 2018 pada pasal 5 ayat (1) Jangka waktu tertentu pengenaan Pajak Penghasilan yang bersifat final sebagaimana dimaksud dalam Pasal 2 ayat (1) yang paling lama: a. 7 (tujuh) tahun pajak bagi wajib pajak orang pribadi; b. 4 (empat) tahun pajak bagi wajib pajak badan berbentuk koperasi, persekutuan komanditer, atau firma; dan c. 3 (tiga) tahun pajak bagi wajib pajak badan berbentuk perseroan terbatas. Maka perusahaan yang sudah berjalan pada masing-masing kriteria akan kembali menggunakan tarif pasal 17 ayat (1) huruf a, pasal 17 ayat (2a), atau pasal 3E Undang-Undang Pajak Penghasilan. Pasal 17 itu pengenaan tarif pajaknya $12,5 \%$ dari laba bersih untuk perusahaan yang peredaran brutonya kurang dari 4,8 miliar setahun.

Melihat Peraturan Pemerintah no 23 tahun 2018 ini, muncul masalah akibat adanya peraturan di pasal 5 ayat (1) bahwa ada jangka waktu penggunaan tarif pajak penghasilan yang bersifat final untuk para pelaku usaha UMKM atau perusahaan informal yang memiliki peredaran bruto kurang dari 4,8 miliar. Perusahaan UMKM dan perusahaan informal wajib kembali dikenai tarif pasal 17 yaitu pengenaan pajak penghasilan sebesar $12,5 \%$ dari laba sebelum pajak, sehingga diwajibkan melakukan pembukuan untuk pengenaan pajak terutangnya berdasarkan SAK. Dari hal inilah yang mendorong peneliti untuk mengangkat fenomena yang terjadi, kemudian melakukan penelitian pada pelaku usaha UMKM dan perusahaan informal mengenai kesiapan praktik akuntansi yang sesuai SAK sebagai dasar pengenaan pajak penghasilan menuju PPh pasal 17.

Berdasarkan latar belakang di atas, maka rumusan masalah yang akan diangkat dalam penelitian ini adalah bagaimana kesiapan pelaku usaha UMKM dan perusahaan informal dalam menghadapi perubahan tarif pengenaan pajak pengahasilan dan apakah pelaku usaha UMKM dan perusahaan informal telah diberikan pemahaman mengenai Praktik Akuntansi yang sesuai SAK, dan bukan hanya teknik dasar akuntansi pada saat pengenaan pajak penghasilannya.

Merujuk dari latar belakang dan rumusan masalah yang ada, maka tujuan utama dilakukannya penelitian ini yaitu untuk mengetahui kesiapan para pelaku usaha UMKM dan perusahaan informal dalam menghadapi perubahan tarif pengenaan pajak penghasilan dan mengetahui pelaku 
Utsman \& Rika Syahadatina : Mengungkap kesiapan Praktik Akuntansi Pada .....

usaha UMKM dan perusahaan informal dalam memahami mengenai Standar Akuntansi sebagai dasar pengenaan pajak pengahasilannya.

\section{LANDASAN TEORI}

\section{Proprietary Accounting}

Pengusaha kecil yang menjalankan usaha dan mengatur keuangan sendiri atau dengan kata lain secara keseluruhan semua dilihat dari sudut pandang pemilik sering disebut sebagai Proprietary. Tujuan utama teori proprietary adalah untuk menentukan dan menganalisis kekayaan bersih pemilik, dengan persamaan akuntansi:

\section{Aset $\boldsymbol{~}$ Hutang $=$ Ekuitas Pemilik}

Persamaan ini dibaca: pemilik memiliki aset dan sekaligus memiliki kewajiban, sehingga kekayaan bersihnya adalah kekayaan perusahaan dikurangi dengan kewajiban perusahaan (Mulawarman, 2009).

Proprietary accounting merupakan substansi dasar tujuan usaha, jenis modal, kewajiban yang dapat dilihat dan dicatat sendiri oleh pemilik (Mulawarman, 2013). Isgiyarta (2009) menjelaskan bahwa dalam proprietary theory, perusahaan merupakan milik pemegang saham sehingga posisi utang akan mengurangi kekayaan perusahaan dan bunga diperlakukan sebagai beban usaha. Berdasarkan teori atau pengertian akuntansi oleh beberapa ahli di atas, maka penelitian ini lebih cenderung ke proprietary accounting (akuntansi perseorangan).

Pandangan kepemilikian dalam akuntansi dikembangkan pada usaha kecil, terutama perseorangan dan kemitraan. Namun dengan munculnya perusahaan, teori ini terbukti tidak memadai sebagai dasar untuk menjelaskan akuntansi perusahaan. Secara hukum, perusahaan adalah entitas yang terpisah dari pemilik dan memiliki hak sendiri. Dengan demikian, dibutuhkan kepemilikan aset dan mengasumsikan kewajiban bisnis bukan pemegang saham.

\section{Jangka Waktu PPh Bersifat Final}

Tidak selamanya pelaku usaha dengan peredaran bruto dibawah Rp. 4.800.000.000 mendapatkan fasilitas tarif $0,5 \%$. Dijelaskan tarif pajak pengahasilan yang bersifat final PP no 23 tahun 2018 pada pasal 5, yaitu:

(1) Jangka waktu tertentu pengenaan Pajak Penghasilan yang bersifat final sebagaimana dimaksud dalam Pasal 2 ayat (1) yang paling lama:

a. 7 (tujuh) tahun pajak bagi wajib pajak orang pribadi;

b. 4 (empat) tahun pajak bagi wajib pajak badan berbentuk koperasi, persekutuan komanditer, atau firma; dan

c. 3 (tiga) tahun pajak bagi wajib pajak badan berbentuk perseroan terbatas.

(2) Jangka waktu sebagaimana dimaksud pada ayat (1) terhitung sejak: 
a. Tahun Pajak Wajib Pajak terdaftar, bagi Wajib Pajak yang terdaftar sejak berlakunya Peraturan Pemerintah ini, atau

b. Tahun Pajak berlakunya Peraturan Pemerintah ini, bagi Wajib Pajak yang telah terdaftar sebelum berlakunya Peraturan Pemerintah ini.

\section{METODE PENELITIAN}

Penelitian ini menggunakan pendekatan penelitian kualitatif. Menurut Creswell (2015), penelitian kualitatif merupakan metode-metode untuk mengeksplorasi dan memahami makna yang oleh sejumlah individu atau sekelompok orang dianggap berasal dari masalah sosial atau kemanusiaan. Penelitian ini menggunakan rancangan penelitian studi kasus. Dikatakan studi kasus, karena yang menjadi fenomena yang akan dilakukan penelitian ini adalah pemahaman tentang laporan keuangan untuk dasar pengenaan pajak para informan. Jadi yang menjadi kasus adalah pemahaman mendalam tentang kesiapan UMKM dan usaha Informal dalam mengimplementasikan laporan keuangan berbasis SAK.

Penelitian ini dilakukan dengan mengumpulkan data-data baik wawancara langsung dengan informan, menginterpretasikan makna dibalik kehidupan para responden yang memiliki berbagai macam latar belakang pendidikan dan data pendukung lainnya mengenai pemahaman laporan keuangan pada UMKM di Kabupaten Kota Pamekasan.

Teknik pengumpulan datanya yaitu dengan cara wawancara. Wawancara terstruktur (structured interviews) menurut Sekaran (2006) adalah wawancara yang diadakan ketika diketahui pada permulaan informasi apa yang diperlukan. Teknik analisis data penelitian menggunakan kuesioner penelitian dengan beberapa pertanyaan kepada responden, sehingga peneliti mendapatkan data berupa pemahaman mereka tentang laporan keuangan sebagai kesiapan praktik akuntansi pada perusahaan UMKM dan Informal menuju PPh Pasal 17.

Adapun beberapa cara yang harus dilakukan peneliti dalam hal koleksi data dengan cara wawancara, (1) metode wawancara dilakukan dengan cara memberikan kuesioner berupa pertanyaan semi terbuka, cara ini dapat memicu kedekatan hubungan peneliti dengan informan karena pertanyaan tidak dibatasi dengan pilihan jawaban yang dibuat peneliti. (2) topik yang menjadi bahan wawancara adalah pemahaman dari sosialisasi yang dilakukan kantor pajak, Human Resources (HR) wajib pajak, lembaga pendidikan, akuntan, otodidak, dan karyawan staf akuntansi (3) mentransipkan hasil wawancara dan mengkalisifikasikannya sesuai dengan kelas usaha UMKM dan Informal. (4) menyiapkan data untuk dianalisis. 


\section{Demografis Responden \\ Demografis responden berdasarkan bentuk usaha}

HASIL DAN PEMBAHASAN

Hasil pengolahan data dari follow up responden diketahui bentuk usaha terdiri dari $78.9 \%$ perusahaan perseorangan, sebanyak 5,3\% berbentuk Perseroan Terbatas (PT) dan sebanyak 15,8\% berbentuk koperasi dan CV. Responden menjalankan usahanya di Kota Pamekasan yang dilihat dari lokasi usaha berada di Jln. KH Amin Jakfar, P.Diponegoro, Segara, Kabupaten, Dirgahayu, Parteker, Jokotole. Berdasarkan hasil pengolahan data, terlihat bahwa UMKM dan Usaha Informal yang menjadi responden merata di berbagai lokasi di Kota Pamekasan.

\section{Demografis responden berdasarkan kepemilikan NPWP}

Dari hasil pengolahan data diketahui bahwa responden telah memiliki NPWP. Untuk pelaporan SPT tahunan ada sebesar $41 \%$ Wajib Pajak yang belum melaporkan dan sebanyak $58,3 \%$ sudah melaporkan SPT tahunannya.

\section{Demografis responden berdasarkan posisi di perusahaan}

Berdasarkan posisi di perusahaan diketahui bahwa mayoritas responden sebagai pemilik usaha sebanyak $75 \%$, sebagai direktur perusahaan sebesar $8,3 \%$, dan sebagai manajer keuangan/staf akuntansi sebesar $16,7 \%$.

\section{Demografis responden menurut latar belakang pendidikan}

Hasil pengolahan data diketahui latar belakang pelaku usaha di Pamekasan yang menjadi responden adalah sebanyak 33,3\% lulusan SMA, sebanyak $25 \%$ lulusan sarjana akuntansi, dan sebanyak $8,3 \%$ terdiri dari lulusan ekonomi, manajemen, SMK busana, apoteker.

\section{Pemahaman Standar Akuntansi Keuangan}

Berdasarkan olah data yang telah dilakukan untuk variabel pemahaman SAK menunjukkan bahwa sebanyak $75 \%$ pelaku usaha UMKM dan Informal tidak memahami SAK, bahkan yang melakukan pencatatan/pembukuan hanya sebagian transaksi sebesar $66,7 \%$ dan yang melakukan pencatatan penuh semua transaksi itu sebanyak 33,3\%, karena pelaku usaha UMKM tersebut menggunakan software akuntansi.

Minimnya sosialisasi yang dilakukan oleh lembaga-lembaga terkait, berdampak pada pemahaman laporan keuangan pelaku usaha UMKM dan Informal sangat rendah dengan ditunjukkan dari hasil olah data, sebasar $41,7 \%$ menjawab tidak mengerti/tidak paham cara membuat laporan keuangan. Sebesar 58,3\% pelaku usaha UMKM dan Informal memperoleh pemahaman untuk membuat laporan keuangan. Pemahaman tersebut 


\section{$D A A$}

Vol. 5, No. 1, Oktober 2020

berasal dari sosialisasi atau pemahaman instansi pemerintah dalam hal ini kantor pajak 8,3\%, kantor akuntan 8,3\%, otodidak 8,3\%, lembaga pendidikan $25 \%$, dan karyawan staf akuntansi sebesar $8,3 \%$.

\section{SIMPULAN}

Berdasarkan hasil analisis mengenai pemahaman pelaku usaha UMKM dan Informal, sebesar 58,3\% mengerti cara membuat laporan keuangan dan $41,7 \%$ tidak mengerti/tidak paham cara membuat laporan keuangan. Pemahaman pelaku usaha UMKM dan Informal ini diperoleh dari lembaga pendidikan yaitu pada saat studi di perguruan tinggi fakultas ekonomi dan mengambil jurusan akuntansi atau manajemen sebesar $25 \%$, kemudian sebesar $8,3 \%$ diperoleh pemahaman juga dari staf akuntansi yang dipekerjakan oleh pemilik usaha, memakai jasa akuntan profesional sebesar 8,3\%, dan sisanya sebesar 8,3\% diperoleh dari sosialisasi kantor pajak. Melihat kondisi seperti ini, kami menyimpulkan bahwa pelaku usaha UMKM dan Infromal belum siap untuk beralih ke PPh pasal 17 UU no 46 tahun 2013. Yang sebagaimana di atur bahwa usaha perseorangan, koperasi, CV, firma, dan PT akan kembali dikenai beban pajak berdasarkan perhitungan tarif pph pasal 17 dari laba bersih yang mengharuskan membuat laporan keuangan. Hal ini dapat dilihat juga dengan lemahnya pemahaman SAK ETAP, UMKM, IFRS maupun Syariah yang dibuktikan dengan nilai presentase yang kecil yaitu hanya sebesar $33,3 \%$ yang mengetahui SAK. Maka dari itu sosialisasi dari pihak yang berkepentingan sangat diperlukan terutama HR yang diberikan kepercayaan sebagai mentor yang menangani beberapa Wajib Pajak. Pemahaman juga telah diberikan oleh lemabaga pendidikan, akuntan profesional, dan pemahaman secara mandiri/otodidak juga sangat membantu pelaku usaha dalam membuat laporan keuangan sebagai dasar pengenaan beban pajaknya.

\section{DAFTAR PUSTAKA}

Agustuliani, A. dan J. Majid. Implementasi Nilai Itsar Membangun Konsep Harga Jual pada Pasar Pannampu Makassar. Jurnal Ilmiah Akuntansi Peradaban, 1(1): 21-40. 2016

Creswell, J. W. Penelitian Kualitatif dan Desain Riset (Memilih di Antara Lima Pendekatan). Yogyakarta: Pustaka Pelajar. 2015.

Haris, D.M. Strategi Pengembangan Usaha Sektor Informal Dalam Mendukung Pertumbuhan Ekonomi dan Penanggulangan Kemiskinan di Perkotaan. Proceeding Simposium Nasional Otonomi Daerah. Universitas Sultan Ageng Tirtayasa. 2011.

Hart, K. Informal Income Opportunities and Urban Employment in Ghana. Journal of Modern African Studies, 11 (1): 61-89. 1973. 
Isgiyarta J. Teori Akuntansi dan Laporan Keuangan Islami. Semarang: Badan Penerbit Universitas Diponegoro. 2009.

Juardi, M. S. S. Mengungkap Praktik Akuntansi Supir Panther (Sebuah Studi Etnometodologi). Jurnal Masagena, 11(2): 295-313. 2016

Kamayanti, A. Metodologi Penelitian Kualitatif Akuntansi, Pengantar Religiositas Keilmuan. Jakarta: Yayasan rumah peneleh. 2016.

Kementerian Keuangan Republik Indonesia, 2018. APBN 2018. Didapat di https://www.kemenkeu.go.id/apbn2018 diakses 3 Maret 2019.

Mulawarman, A. D. 2009. Akuntansi Syariah: Teori Konsep dan Laporan Keuangan. Jakarta: Epublishing Company. 2009.

Mulawarman, A. D. Nyanyian Metodologi Akuntansi Ala Nataatmadja: Melampaui Derridian Mengembangkan Pemikiran Bangsa "Sendiri". Jurnal Akuntansi Multiparadigma, 4(1): 149-164. 2013.

Musmini, S. L. Sistem Informasi Akuntansi Untuk Menunjang Pemberdayaan Pengelolaan Usaha Kecil: Studi Kasus Pada Rumah Makan Taliwang Singaraja. Vokasi Jurnal Riset Akuntansi, 2 (1): 6281. 2013

Peraturan Pemerintah Republik Indonesia No 23 Tahun 2018. Tentang Pajak Penghasilan Atas Penghasilan Dari Usaha Yang Diterima Atau Diperoleh Wajib Pajak Yang Memiliki Peredaran Bruto Tertentu. Direktorat Jenderal Pajak, Departemen Keuangan Republik Indonesia. Jakarta.

Sakri,N. Majid, J. dan Juardi, M,S,S. Mengungkap Informasi Akuntansi Usaha Kecil (Sebuah Studi Fenomenologi. Jurnal IImiah Akuntansi Peradaban, 4 (2): 75-100. 2018.

Sekaran, U. Research Methods for Business, Metodologi Penelitian Bisnis. Jakarta: Salemba Empat. 2006

Sugiyono. Metode Penelitian Kuantitatif Kualitatif dan R\&D. Bandung: Alfabeta. 2013.

Triyuwono, I. Mengangkat "Sing Liyan" untuk Formulasi Nilai Tambah Syariah. Jurnal Akuntansi Multiparadigma, 2(2): 186-200. 2011.

Undang-Undang No 36 Tahun 2008 dan Peraturan Pemerintah RI Tahun 2008 Tentang Pajak Penghasilan, Direktorat Jenderal Pajak, Departemen Keuangan Republik Indonesia. Jakarta.

Undang-Undang No 46 Tahun 2013 dan Peraturan Pemerintah RI Tahun 2013 Tentang Pajak Penghasilan Atas Penghasilan Dari Usaha Yang Diterima Atau Diperoleh Wajib Pajak Yang Memiliki Peredaran Bruto Tertentu. Direktorat Jenderal Pajak, Departemen Keuangan Republik Indnesia. Jakarta 